\title{
DEPRESI, PERILAKU NARSISISTIK SERTA PERANAN TEAMWORK DALAM MENCAPAI KESUKSESAN BEKERJA
}

\author{
FIRMAN FIRMAN \\ Staf Pengajar Jurusan Bimbingan dan Konseling FIP Univ.Negeri Padang \\ EMAIL : firman@konselor.org
}

\begin{abstract}
Perkembangan ekonomi yang cepat, perampingan organisasi, PHK, merger dan bangkrutnya beberapa perusahaan sebagai akibat dari krisis ekonomi yang berkepanjangan telah menimbulkan dampak yang sangat merugikan bagi ribuan bahkan jutaan tenaga kerja. Kegoncangan organisasi tidak jarang menyebabkan menurunnya motivasi kerja. Para pekerja di setiap level mengalami tekanan dan ketidakpastian. Situasi ini seringkali memicu terjadinya stress kerja. Stres kerja yang dialami seseorang kadang-kadang berlanjut ke tingkat depresi. Depresi yang dialami karyawan tidak jarang menyebaban penurunan produktifitas kerja. Makalah ini mengupas : (1) depresi, penyebab dan gejalanya, (2) perilaku narsisistik dalam organisasi serta (3) peranan teamwork dalam mencapai kesuksesan kerja.
\end{abstract}

\section{A. Depresi Penyebab dan Gejalanya}

Depresi biasanya terjadi saat stress yang dialami oleh seseorang tidak kunjung reda, dan depresi berkorelasi dengan kejadian dramatis yang menimpa seseorang, misalnya kematian seseorang yang sangat dicintai atau kehilangan pekerjaan yang sangat dibanggakan. Depresi adalah masalah yang bisa dialami oleh siapapun di dunia ini. Sebuah penelitian di Amerika, 1 dari 20 orang di Amerika setiap tahun mengalami depresi, dan paling tidak 1 dari 5 orang pernah mengalami depresi sepanjang sejarah kehidupan mereka. Di Indonesia, banyak kasus depresi terjadi sebagai akibat dari krisis yang melanda beberapa tahun belakangan ini. Masalah PHK, sulitnya mencari pekerjaan, sulitnya mempertahankan pekerjaan dan krisis keuangan adalah masalah yang sekarang ini sangat umum menjadi pendorong timbulnya depresi di kalangan profesional.

Phillip L. Rice (1992), depresi adalah gangguan mood, kondisi emosional berkepanjangan yang mewarnai seluruh proses mental (berpikir, berperasaan dan berperilaku) seseorang. Pada umumnya mood yang secara dominan muncul adalah perasaan tidak berdaya dan kehilangan harapan.

Individu yang pernah mengalami depresi tanpa tahu sebab musababnya sampai membuat ia semakin depresi karena tidak ketemu jawabannya. Akhirnya jadi uring-uringan sendiri, semua jadi serba salah karena tak seorang pun yang bakal memahami masalah tersebut Sebenarnya penyebab depresi bisa dilihat dari faktor biologis (seperti misalnya karena sakit, pengaruh hormonal, depresi pascamelahirkan, penurunan berat yang drastis) dan faktor psikososial (misalnya konflik 
individual atau interpersonal, masalah eksistensi, masalah kepribadian, masalah keluarga)

Individu yang terkena depresi pada umumnya menunjukkan gejala psikis, gejala fisik \& sosial yang khas, seperti murung, sedih berkepanjangan, sensitif, mudah marah dan tersinggung, hilang semangat kerja, hilangnya rasa percaya diri, hilangnya konsentrasi dan menurunnya daya tahan. Gejala depresi adalah kumpulan dari perilaku dan perasaan yang secara spesifik dapat dikelompokkan sebagai depresi. Namun yang perlu diingat, setiap orang mempunyai perbedaan yang mendasar, yang memungkinkan suatu peristiwa atau perilaku dihadapi secara berbeda dan memunculkan reaksi yang berbeda antara satu orang dengan yang lain. Gejala-gejala depresi ini bisa kita lihat dari tiga segi, yaitu fisik, psikis dan sosial.

Gejala Fisik yang mudah dideteksi sebagai akibat dari depresi adalah : (1) gangguan pola tidur (sulit tidur, terlalu banyak atau terlalu sedikit), (2) menurunnya tingkat aktifitas, orang yang mengalami depresi menunjukkan perilaku yang pasif, menyukai kegiatan yang tidak melibatkan orang lain seperti nonton TV, makan, tidur , (3) menurunnya efesiensi kerja. Penyebabnya jelas, orang yang terkena depresi akan sulit memfokuskan perhatian atau pikiran pada suatu hal, atau pekerjaan. Sehingga, mereka juga akan sulit memfokuskan energi pada hal-hal prioritas. Kebanyakan yang dilakukan justru hal-hal yang tidak efisien dan tidak berguna, seperti misalnya ngemil, melamun, merokok terus menerus, sering menelpon yang tak perlu. Yang jelas, orang yang terkena depresi akan terlihat dari metode kerjanya yang menjadi kurang terstruktur, sistematika kerjanya jadi kacau atau kerjanya jadi lamban, (4) menurunnya produtifitas kerja, orang yang terkena depresi akan kehilangan sebagian atau seluruh motivasi kerjanya. Sebabnya, ia tidak lagi bisa menikmati dan merasakan kepuasan atas apa yang dilakukannya. Ia sudah kehilangan minat dan motivasi untuk melakukan kegiatannya seperti semula. Oleh karena itu, keharusan untuk tetap beraktivitas membuatnya semakin kehilangan energi karena energi yang ada sudah banyak terpakai untuk mempertahankan diri agar tetap dapat berfungsi seperti biasanya. Mereka mudah sekali lelah, capai padahal belum melakukan aktivitas yang berarti, (5) mudah merasa rendah diri dan sakit. Depresi itu sendiri adalah perasaan negatif. Jika seseorang menyimpan perasaan negatif maka jelas akan membuat letih karena membebani pikiran dan perasaan ; dan ia harus memikulnya di mana saja dan kapan saja, suka tidak suka .

Gejala psikis akibat depresi ditandai oleh: (1) kehilangan rasa percaya diri. Penyebabnya, orang yang mengalami depresi cenderung memandang segala sesuatu dari sisi negatif, termasuk menilai diri sendiri. Pasti mereka senang sekali membandingkan antara dirinya dengan orang lain. Orang lain dinilai lebih sukses, pandai, beruntung, kaya, lebih berpendidikan, lebih berpengalaman, lebih diperhatikan oleh atasan, dan pikiran negatif lainnya, (2) sensitif dan senang sekali mengkaitkan segala sesuatu dengan dirinya. Perasaannya sensitif sekali, sehingga sering peristiwa yang netral jadi dipandang dari sudut pandang yang berbeda oleh mereka, bahkan disalah artikan. Akibatnya, mereka mudah tersinggung, mudah 
marah, perasa, curiga akan maksud orang lain (yang sebenarnya tidak ada apaapa), mudah sedih, murung, dan lebih suka menyendiri, (3) merasa diri tidak berguna. Perasaan tidak berguna ini muncul karena mereka merasa menjadi orang yang gagal terutama di bidang atau lingkungan yang seharusnya mereka kuasai. (4) perasaan bersalah. Perasaan bersalah terkadang timbul dalam pemikiran orang yang mengalami depresi. Mereka memandang suatu kejadian yang menimpa dirinya sebagai suatu hukuman atau akibat dari kegagalan mereka melaksanakan tanggung jawab yang seharusnya dikerjakan. Banyak pula yang merasa dirinya menjadi beban bagi orang lain dan menyalahkan diri mereka atas situasi tersebut, (5) perasaan terbebani. Banyak orang yang menyalahkan orang lain atas kesusahan yang dialaminya. Mereka merasa terbeban berat karena merasa terlalu dibebani tanggung jawab yang berat.

Depresi berawal dari diri sendiri pada akhirnya mempengaruhi lingkungan dan pekerjaan (atau aktivitas rutin lainnya).Lingkungan tentu akan bereaksi terhadap perilaku orang yang depresi tersebut yang pada umumnya negatif (mudah marah, tersinggung, menyendiri, sensitif, mudah letih, mudah sakit). Problem sosial yang terjadi biasanya berkisar pada masalah interaksi dengan rekan kerja, atasan atau bawahan. Masalah ini tidak hanya berbentuk konflik, namun masalah lainnya juga seperti perasaan minder, malu, cemas jika berada di antara kelompok dan merasa tidak nyaman untuk berkomunikasi secara normal. Mereka merasa tidak mampu untuk bersikap terbuka dan secara aktif menjalin hubungan dengan lingkungan sekalipun ada kesempatan.

\section{B. Perilaku Narsisistik Dalam Organisasi}

Konsep dan istilah narsisisme atau narsisistik berawal dari mitologi Yunani kuno tentang seorang pemuda tampan yang bernama Narsisus. Narsisus adalah putra dewa sungai, Cephissus. Pada saat itu Echo, seorang dewi yang tidak bisa berbicara, jatuh cinta kepadanya. Namun Narcisus bertindak kejam dan menolak cinta Echo. Pada suatu hari, Narsisus melewati sebuah danau yang sangat bening airnya dan ia melihat refleksi dirinya sendiri. Ia sangat mengagumi dan jatuh cinta pada refleksi itu. Ia sangat ingin menjamah dan memiliki wajah yang dilihatnya, tapi setiap kali ia mengulurkan tangannya untuk meraih refleksi dirinya, bayangan itu kemudian menghilang. Narsisus tetap menunggu di tepi danau untuk mendapatkan bayangan yang menjadi obyek kekagumannya sampai ia mau menceburkan dirinya sendiri ke dalam danau dan akhirnya mati. Para dewa merasa kasihan padanya, sehingga Narsisus ditranformasikan menjadi tumbuhan berbunga yang diberi nama Narsisus. Mitologi ini digunakan dalam Psikologi pertama kalinya oleh Sigmund Freud (1856-1939) untuk menggambarkan individuindividu yang menunjukkan cinta diri yang berlebihan. Freud menamakan mereka : "The narsissists" dan pelakunya disebut individu narsisistik atau seorang narsisis.

Menurut Freud individu narsisistik adalah mereka yang senang dikagumi, sangat independent dan tidak mudah didekati. Mereka adalah innovator di perusahaan dan sangat terpacu untuk memperoleh kekuasaan dan kejayaan. Mereka dikenal 
sebagai pemimpin yang penuh visi dan memiliki banyak pengikut. Namun demikian mereka juga memiliki kekurangan yaitu tidak mau menerima kritik, kurang empathy, bukan pendengar yang baik, sulit dibimbing dan membimbing orang lain, dan memiliki jiwa kompetisi yang cenderung berlebih-lebihan.

Buss dan Chiodo (1991) perilaku sehari-hari individu-individu narsisistik dikategorikan dalam 8 kategori sebagai berikut: (1) perilaku narsisistik yaitu bercermin dan berdandan secara konstan, memancing pujian orang lain, menanyakan persepsi orang lain tentang dirinya, selalu menonjolkan kinerja dan prestasinya, mencela kemampuan dan merendahkan prestasi orang lain, dan selalu membandingkan dirinya dengan orang lain, (2) perilaku eksibiosionie, yaitu menjadi pusat perhatian dalam perkumpulan, menghamburkan uang untuk membuat orang lain kagum, berbicara keras-keras supaya orang lain mendengar, membantah demi menarik perhatian, dan suka memamerkan harta miliknya, (3) perilaku gradiose, yaitu mengharapkan orang lain untuk mengalah, menghindarkan diri dari orang yang dianggapnya lebih rendah, menyatakan betapa hebatnya dia, mengambil alih pimpinan rapat, menominasikan diri sebagai orang yang memiliki kekuasaan. (4) perilaku terpusat pada diri sendiri(self centred) yaitu membuat keputusan tanpa mengindahkan orang, memaksa orang lain untuk mendengarkan ceritanya tanpa mau mendengar cerita orang lain, tidak mau berbagi dengan orang lain, meminta orang lain untuk mengikuti jadwalnya, (5) entitlemen, yaitu meminjam tanpa berniat mengembalikan, datang pada saat yang tidak tepat dan mengharapkan untuk dilayani, mengundang diri sendiri ke pesta, menggunakan milik orang lain tanpa meminta ijin dahulu, menuntut perlakuan istimewa yang bukan pada tempatnya, perilaku ekspansif (self-aggrandizing): senang menonjolkan kekayaannya, hanya mau bersosialisasi dengan orang ternama dan berstatus tinggi, senang menunjukkan kesalahan orang lain, datang terlambat pada saat meeting untuk menunjukkan bahwa ia penting dan memukau, (6) perilaku tidak empaik, tidak menghiraukan perasaan orang lain, tidak berduka ketika orang lain mengalami musibah, tidak mau mendengar masalah yang dihadapi oleh orang lain, menginterupsi percakapan orang lain, (7) perilaku manipulatif, hanya mau melakukan kebaikan dengan pamrih, meminta orang lain untuk mengerjakan pekerjaannya dan perilaku manipulatif lainnya.

\section{Peranan Teamwork Untuk Mencapai Kesuksesan Kerja.}

Dalam dunia usaha, penggunaan teamwork seringkali merupakan solusi terbaik untuk mencapai suatu kesuksesan. Teamwork yang solid akan memudahkan manajemen dalam mendelegasikan tugas-tugas organisasi. Namun demikian untuk membentuk sebuah team yang solid dibutuhkan komitment tinggi dari manajemen. Hal terpenting adalah bahwa teamwork harus dilihat sebagai suatu sumber daya yang harus dikembangkan dan dibina sama seperti sumber daya lain yang ada dalam perusahaan. Proses pembentukan, pemeliharaan dan pembinaan teamwork harus dilakukan atas dasar kesadaran penuh dari team tersebut sehingga segala sesuatu berjalan 
secara normal sebagai suatu aktivitas sebuah teamwork, meskipun pada kondisi tertentu manajemen dapat melakukan intervensi.

Secara umum teamwork dapat didefinisikan sebagai kumpulan individu yang bekerjasama untuk mencapai suatu tujuan. Kumpulan individu-individu tersebut memiliki aturan dan mekanisme kerja yang jelas serta saling tergantung antara satu dengan yang lain. Oleh karena itu sekumpulan orang yang bekerja dalam satu ruangan, bahkan didalam satu proyek, belum tentu merupakan sebuah teamwork. Terlebih lagi jika kelompok tersebut dikelola secara otoriter, timbul faksi-faksi di dalamnya, dan minimnya interaksi antar anggota kelompok.

Ketika seseorang bekerja didalam kelompok (team), akan ada dua isu yang muncul. Pertama adalah adanya tugas-tugas (task) dan masalah-masalah yang berhubungan dengan pelaksanaan pekerjaan. Hal ini seringkali merupakan topik utama yang menjadi perhatian team. Kedua adalah proses yang terjadi di dalam teamwork itu sendiri, misalnya bagaimana mekanisme kerja atau aturan main sebuah team sebagai suatu unit kerja dari perusahaan, proses interaksi di dalam team, dan lain-lain. Dengan kata lain proses menunjuk pada semangat kerjasama, koordinasi, prosedur yang harus dilakukan dan disepakati seluruh anggota, dan hal-hal lain yang berguna untuk menjaga keharmonisan hubungan antar individu dalam kelompok itu. Tanpa memperhatikan proses maka sebuah teamwork tidak akan memiliki nilai apa-apa bagi perusahaan dan hanya akan menjadi sumber masalah bagi perusahaan dalam pembentukan sebuah teamwork. Sebaliknya jika proses tersebut ada dalam sekumpulan orang yang bekerjasama, maka performance mereka akan meningkat karena akan mendapat dukungan secara teknis maupun moral.

Teamwork merupakan sarana yang sangat baik dalam menggabungkan berbagai talenta dan dapat memberikan solusi inovatif suatu pendekatan yang mapan. selain itu ketrampilan dan pengetahuan yang beranekaragam yang dimiliki oleh anggota kelompok juga merupakan nilai tambah yang membuat teamwork lebih menguntungkan jika dibandingkan seorang individu yang brilian sekalipun.

Sebuah team dapat dilihat sebagai suatu unit yang mengatur dirinya sendiri. Rentangan ketrampilan dan pengetahuan yang dimiliki anggota dan self monitoring" yang ditunjukkan oleh masing-masing team memungkinkannya untuk diberikan suatu tugas dan tanggungjawab. Bahkan ketika suatu masalah tersebut dapat diputuskan oleh satu orang saja, melibatkan teamwork akan memberikan beberapa keuntungan. Keuntungan tersebut adalah: pertama keputusan yang dibuat secara bersama-sama akan meningkatkan motivasi team dalam pelaksanaanya. Kedua, keputusan bersama akan lebih mudah dipahami oleh team dibandingkan jika hanya mengandalkan keputusan dari satu orang saja.

Bila dilihat dari perspektif individu, dengan masuknya ia kedalam suatu kelompok (team) maka hal tersebut akan menambah semangat 
juang/motivasi untuk mencapai suatu prestasi yang mungkin tidak akan pernah dapat dicapai seorang diri oleh individu tersebut. Hal ini dapat terjadi karena team mendorong setiap anggotanya untuk memiliki wewenang dan tanggungjawab sehingga meningkatkan harga diri setiap orang.

Secara umum perkembangan suatu team dapat dibagi dalam 4 tahap: (1) forming, adalah tahapan dimana para anggota setuju untuk bergabung dalam suatu team. Karena kelompok baru dibentuk maka setiap orang membawa nilai-nilai, pendapat dan cara kerja sendiri-sendiri. Konflik sangat jarang terjadi, setiap orang masih sungkan, malu-malu, bahkan seringkali ada anggota yang merasa gugup. Kelompok cenderung belum dapat memilih pemimpin (kecuali team yang sudah dipilih ketua kelompoknya terlebih dahulu), (2) storming adalah tahapan dimana kekacauan mulai timbul di dalam team. Pemimpin yang telah dipilih seringkali dipertanyakan kemampuannya dan anggota kelompok tidak ragu-ragu untuk mengganti pemimpin yang dinilai tidak mampu. Faksi-faksi mulai terbentuk, terjadi pertentangan karena masalah-masalah pribadi, semua ngotot dengan pendapat masing-masing. Komunikasi yang terjadi sangat sedikit karena masing-masing orang tidak mau lagi menjadi pendengar dan sebagian lagi tidak mau berbicara secara terbuka, (3) norming adalah tahapan dimana individu-individu dan sub-group yang ada dalam team mulai merasakan keuntungan bekerja bersama dan berjuang untuk menghindari team tersebut dari kehancuran (bubar). Karena semangat kerjasama sudah mulai timbul, setiap anggota mulai merasa bebas untuk mengungkapkan perasaan dan pendapatnya kepada seluruh anggota team. Selain itu semua orang mulai mau menjadi pendengar yang baik. Mekanisme kerja dan aturanaturan main ditetapkan dan ditaati seluruh anggota serta (4) performing adalah tahapan ini merupakan titik kulminasi dimana team sudah berhasil membangun system yang memungkinkannya untuk dapat bekerja secara produktif dan efisien. Pada tahap ini keberhasilan team akan terlihat dari prestasi yang ditunjukkan.

eterampilan yang diperlukan oleh anggota sebuah teamwork, yaitu: (1) Ketrampilan managerial (Managerial Skills), termasuk kemampuan dalam membuat rencana kerja, menentukan tujuan, memantau kinerja, memonitor perkembangan dan memastikan pekerjaan telah dilakukan secara benar dan (2) keterampilan interpersonal (Interpersonal Skills), termasuk kemampuan berkomunikasi, saling menghargai pendapat orang lain dan kemampuan menjalin hubungan interpersonal dengan orang lain.

\section{KESIMPULAN}

1. Depresi merupakan gangguan mood, kondisi emosional yang berkepanjangan mewarnai seluru proses mental seperti berfikir, perasaan dan perilaku individu. Mood yang muncul secara dominan dalam proses depresi adalah perasaan tidak berdaya dan kehilangan harapan. Depresi 
disebabkan oleh : faktor biologis dan psikososial. Depresi yang dialami individu berakibat kepada kondisi fisik, psikis dan sosial.

2. Perilaku narsisistik merupakan cinta kepada diri sendiri yang senang dikagumi, sangat independen dan sulit untuk didekati.

3. Teamwork sangat bermanfaat untuk mencapai kesuksesan kerja karena keputusan yang dibuat secara bersama akan meningkatkan motivasi kerja,serta keputusan yang diambil mudah dipahami. Individu sebagai anggota team akan bertambah semangat juang/motivasinya. 
MAKALAH

DEPRESI, PERILAKU NARSISISTIK SERTA PERANAN TEAMWORK DALAM MENCAPAI KESUKSESAN BEKERJA

DISUSUN OLEH:

DR. FIRMAN. MS

STAF PENGAJAT JURUSAN BIMBINGAN DAN KONSELING

FAKULTAS ILMU PENDIDIKAN UNIV. NEGERI PADANG

\section{JURUSAN BIBINGAN DAN KONSELING} UNIVERSITAS NEGERI PADANG 